\title{
The Implementation of Service-learning in Typography Class to Design the Cover of Street Vendor Stalls in Surabaya, Indonesia.
}

\author{
Maria Nala Damajanti ${ }^{*}$, and Elisabeth Christine Yuwono \\ Visual Communication Design, Faculty of Art and Design, Petra Christian University, Siwalankerto \\ 121-131, Surabaya 60236, Indonesia
}

\begin{abstract}
Through Service Learning (S-L) program students of Typography 2 class, Visual Communication Design, Petra Christian University, had an opportunity to learn and applied their knowledge. The selected media is street vendor stall's cover (it is known as keber Pedagang Kaki Lima or PKL in Indonesia) at Surabaya. This media usually installed in front of the street vendors stall. The cover material is fabric or outdoor vinyl. S-L itself is a new method which applied to Typography 2 class. S-L method was selected as one of learning method which allows students to implementing typography theories to society. According to S-L application a number of experts requiring benefits of parties involved. In this case it is important to measure the success of S-L considers the balancing benefits of students and PKL communities as the target. Therefore, students not only learning from their interaction with community by doing the cover design process but simultaneously must provide significant benefits of PKL. Through depth interviews researcher found benefits of both parties. Students got real experiences as graphic designers by serving the PKL communities as clients. In the other hand the PKL communities received new covers design as a promotional media for their stall.
\end{abstract}

Keywords: Service learning, Surabaya street vendor, typography

\section{Background}

This research was conducted to identify the implementation and benefits of ServiceLearning (S-L) for Typography 2 students of the even semester of 2015/2016 at the Visual Communication Design Department of Petra Christian University, Surabaya. This research was also carried out to identify the extent of benefits which are directly or indirectly felt by the Street Vendors as S-L's targets. As is widely known, S-L as a learning approach comes with various benefits to the students after having been implemented at a certain stage.

\footnotetext{
*Corresponding author: mayadki@petra.ac.id
} 
In relation to the S-L implementation, the Typography 2 teacher has compiled a Syllabus with the purpose of preparing the students with the hard skill of proper typography according to the applicable standards and the ability to apply it on a certain media based on the specified theme, namely the Street Vendors' stall cover. As such, the teacher has also prepared several procedures to be followed by the students. The procedure entails an explanation to the students regarding the outline of course throughout the semester and their tasks, one of which is the implementation of Service-Learning. Another important material is how to behave and communicate with street vendors in order to obtain a suitable design their business cover according to their needs. In this task, the students are asked to revise the less-than-attractive street vendor's stall cover design with the prerequisite of applying typeface of their own design on the stall cover. Street vendors are selected as S-L targets due to the fact that they are the drivers of the creative economy in Surabaya but are often seen as defacers of the urban landscape because of their arbitrary use of public space. However, street vendors continue to exist and are even hailed as a unique visual cultural phenomenon, as was proposed by Damajanti in her research on Vernacular Typography on Surabaya Street Vendor [1].

This research uses a descriptive-qualitative method as explained by Moleong [2]. The researcher want to have a better understanding as an evaluation on how S-L program had been run in Tyography class. Initially, the researcher define the goal to be achieved according to the program's function, the S-L process and the result of S-L program. Beside the teacher's material, the research data is obtained through reflective analysis of the students, observation of S-L results on site, documentations, focus group discussions and interview with the students, street vendors, tutors, S-L experts and stall customers. Researcher using a Service-learning's guide book from Petra Christian Unversity to conduct the S-L program [3]. Using this method, the researcher expects to comprehend the events unveiling throughout the S-L program as well as the challenges and hindrances faced by the students.

\subsection{Work-based learning}

Researcher as an educator facing the big issue of how to provide circumstances for students to learn optimally in the interim stafe between childhood and adulthooh. As Berry and Chisolm mention in their book, they concern about how institutions of higher education provide environment and direction that will help students to become mature and responsible adults [4]. On the other hand, in this increasingly competitive era, people everywhere must have a multitude of work experience and Work-Based Learning (WBL) becomes more and more important because students are enabled to learn and simultaneously contribute to the society on the side. According to Lynch and Harnish, WBL enables students to develop their attitude, knowledge, skills, enlightenment, behavior, habits and associations based on their experience at campus and workplace, possibly resulting in real work activity learning [5]. The aforementioned facts further justify the significance and needs of having work experience. The author agreed with Berry and Chisholm who questioned the position of a university as an institution which accompanies an individual as he/she enters the world of adulthood. The extent of educational institution's preparation in terms of environment and directions to assist students before they enter the marketplace.

It is, therefore, crucial to provide students with the experience needed to practice their hard-earned knowledge at the workplace, since this is by far the main skillset and prerequisite demanded by most employers. It is also aligned with the principle of ServiceLearning (S-L). The theory of Service-Learning itself was based on the assumption that experience is the basis of learning and various forms of services to the society are important 
in that process. Through S-L, students will have real experience in the society, which will prepare them with the required skill sets for the work place. At the moment, S-L is increasingly prominent among learning methods, especially in the face of global social issues. The S-L Method is a holistic education method which integrates all aspects that must exist within the students: academic aspect, emotional aspect, and spiritual aspect.

However, in reality, Moore and Lin stated that there are many terms, models and paradigms occurring in the implementation of S-L at universities. One way to distinguish it is by identifying the beneficiaries of the $\mathrm{S}-\mathrm{L}$ implementation since that is the most important part of S-L [6]. Similar research with identical scope includes those by Natadjaja, as covered by the International Journal of Visual Design regarding the Implementation of Visual Communication Design Media After Conducting ServiceLearning Program regarding the impact of S-L implementation on Visual Communication Design 3 study at Visual Communication Design Department of Petra Christian University [7]. The similarities are apparent in the fact that this method was carried out after the formal college sessions were completed. Its significance lies in the involvement of local community in implementing the design elements for promotional needs of certain areas/clients. The issue is that not all S-L results are used by the community or areas which become S-L partners. What is different about this research is that the target community of S-L Typography program is street food and beverage vendors which make part of the urban society's small enterprises. Most of them do not have educational backgrounds and this partnership came as a form of support for their business.

\section{Data collecting and data analysis}

The S-L stage itself consists of several processes carried out in classes, at the studio, and on the fields as follows: i) Compilation of Syllabus for Typography class, ii) Introduction to S$\mathrm{L}$, iii) Guide to Conducting S-L and target audience, iv) Guide to creating typeface, rules, and regulations, v) Technical guide to creating banners, vi) Works at the studio, including creating thumbnails, tight tissues and final works, vii) Work on the field, including finding target street vendors, interviews, banner application for final assignment, documentation, viii) Work report and reflections.

Interviews are carried out based on the following procedure: i) Preparations of assignment, introduction to S-L method, ii) Instructions for S-L implementation, iii) Application and iv) Evaluation, including reporting, reflections, and documentation. Researcher concern also on how to make a good preparation material for student especially in doing social service because the students didn't have any experience on that case. Therefore, researcher provide an ethic guidelines that will help student to be succesful in gaining a client, in this case is a street vendor. Students have to be genuine and warm, be sensitive, listen attentionally, listening and talking with clients, try not to use threat, be firm and friendly, dissaprove the act, not the person and explain carefuly the rules of the service. These guidelines was adopted and developed from Unesco's Module 3 for Social Work, edited by Wilma Gaez and John Allen [8].

During the preparations, the teacher asked the students the following questions about their preparations before and during the mentoring process until the assignment is submitted: Are the materials regarding introduction to S-L comprehensive enough? Are the materials regarding instructions for S-L implementation and target audience comprehensive and doable? Are materials regarding the creation of typeface, rules and other regulations comprehensive? Are materials regarding the technical guide to creating stall cover comprehensive? How goes the studio works, including the creation of thumbnail, tight tissue and final assignment? What are the challenges and hindrances of working in a team? How is the field work coming, including the search for target street vendor, interviews and 
consulting? What are the challenges faced when installing stall cover? What are the challenges in reporting and reflection as well as documentation?

The following steps are taken to identify the S-L implementation process: i) The issues faced during the search for design target street vendor, ii) The issues faced during the process from the students and the street vendors' perspectives, iii) challenges during the typeface design process, iv) challenges during the stall cover design process.

The next stage is evaluating the entire implementation of S-L. The following questions were thus posed: i) The benefits felt by the students after participating in S-L, ii) benefits for the street vendors after cooperating with DKV students, iii) the students' impressions and suggestions for the S-L program and the street vendors' perception towards Petra Christian University as a whole and its impacts on their business.

Regarding the consumers' perspective, the author posed the following questions: What is your opinion after realizing that this stall cover was the result of S-L by students of Petra Christian University? How do you feel about this program? What can you suggest to improve this program?

During the S-L preparations, students were given theoretical knowledge in the classroom. They were provided with an understanding of S-L, ethics, its consequences, and possible challenges. Afterward, they were explained about the form of assignments, introduced to the target audience and their business character as well as sociocultural backgrounds of stall owners. This is important regarding the disparate in social standing between the students and the street vendors.

\subsection{Preparations}

The earliest preparation was carried out by the teacher before the class began which included assignment materials and scheduling as well as a distribution of task groups. This assignment was divided into groups due to a large number of participating students. There are 160 students in total, divided into 32 groups. A tutor supervises two groups simultaneously. A tutor is tasked with guiding the students about the technical aspect of the assignment, from street vendor search, typeface design consulting, down to its application on the stall cover. Based on the evaluation performed by the students on the reflection sheet, the process was reported to have been operating smoothly. However, in terms of typeface, several of the students' designs were still inconsistent and affected the outcome of digital typeface design process. As a result, their digital type appeared less than optimal. Luckily the design was perfected upon application on the street vendor's stall cover using a hand-painting technique. 


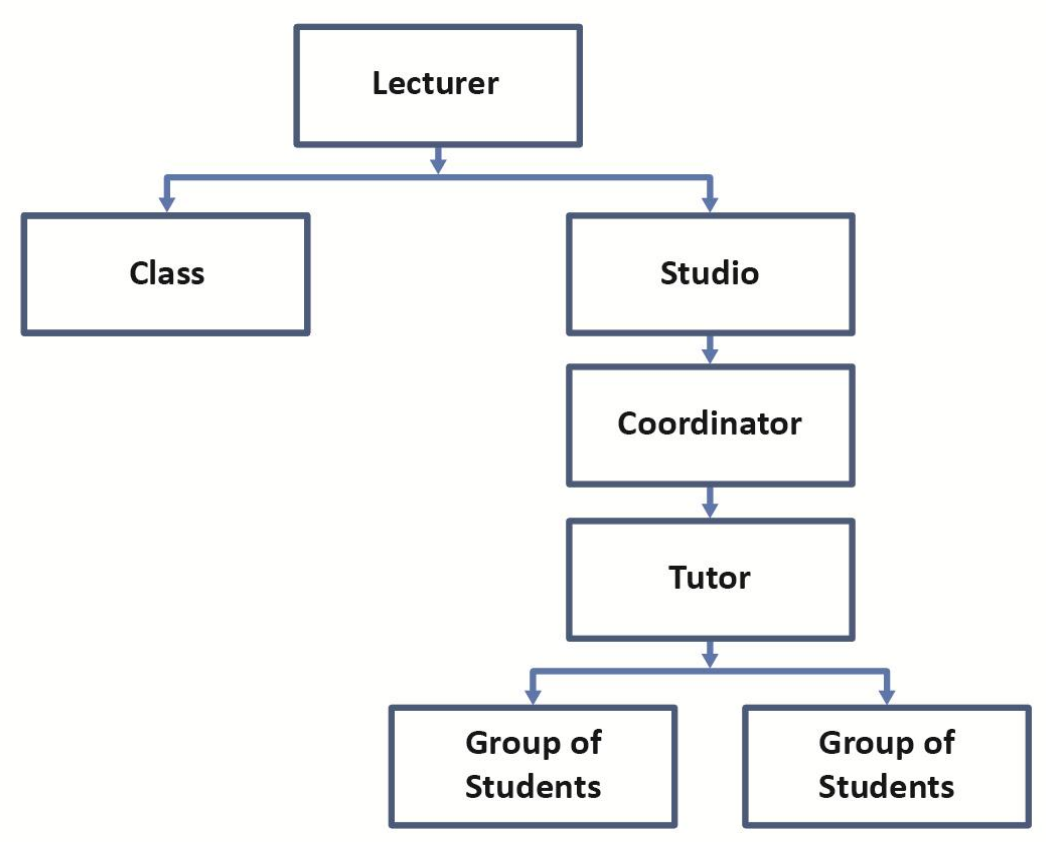

Fig. 1. Typography class and studio learning structure.

Regarding the choice of street vendors, the teacher gave a list of food types to be chosen by the students. Several issues were found during its execution. Several students had chosen a location far from Surabaya - Sidoarjo - which turned out to be temporary location and upon evaluation, the researcher could no longer find the said street vendor. Another issue found during the selection of street vendor is the student's lack of initiative to ask the future business plans of the street vendor. As a result, when the stall cover was to be installed, the said street vendor had relocated out of town, to Kediri. The students were then forced to go out of town to seek the said street vendor and install the redesigned stall's cover.

Next, regarding preparations in the classroom, all materials were found to be comprehensive and doable. Students were able to take step-by-step approach according to schedule. However, one student group had to do more than one field visit due to the street vendors business hours which collided with their class activities. Fortunately, this issue was easily solved by sending some members who were able to leave class at night for an interview and ask the street vendor to become an S-L target. Therefore, it can be concluded that despite being the first time an S-L program was held in a Typography class, no significant issue had occurred in terms of comprehension and execution, especially in the early stages where students had to make field trips to obtain street vendors target according to stipulations.

During the preparations, the students conducted a field survey to determine which street vendor they would like to assist using lecturer's guidelines. During the evaluation, the researcher found several approaches used by the students to find their S-L target: choosing a street vendor located near one of the group member's home; choosing a familiar street vendor to whom they are customers, and street vendors who were specifically interviewed and found to be ready to cooperate. The third procedure was carried out after the students had observed and found several flaws on the street vendor's stall cover. The fourth procedure of search was to ask for the street vendor's readiness regardless of their 
condition. For example, when a street vendor already had a sponsored stall cover, even if the student designed a new stall cover for him the street vendor would not be able to use it because they're bound to a sponsorship agreement, in this case with a cigarette manufacturer. Since the street vendor was located near campus, the researcher believes that the location was the main factor for the student's choice, albeit a poor one. This is of course not in alignment with the spirit of S-L, which is mutual benefits on both sides. Regarding this matter, the researcher hereby encourages tutors to perform a preliminary inspection on the students' choice of a street vendor before giving approval.

In relation to the mobile nature of street vending, the researcher saw it as a challenge to be tackled. The late business hours have forced the surveying students to properly schedule their activities. Such condition also led to the researcher's belief that this particular type of group should be assisted and become S-L targets due to the limited amount of capital which hampers their effort to earn a living for their family. Based on interviews with street vendors, it was found that this type of business tends to be hereditary, having been passed down from one generation to the next in the same family. There were even two S-L targets who happened to be father and son, namely the owners of Sate Ondemohen on Walikota Mustajab street. The owners of the Ondemohen satay are the third generation of the enterprising family. That the father and son became targets of the same S-L were not initially known to the father. The students who chose them to become their S-L target also were not aware of their family ties at first. Unfortunately, the son's satay business had closed down approximately 6 months since he received the stall cover because of family reasons. This was found through an evaluation performed by the researcher on the field. Based on this condition, we can conclude that the street vendor's business was the backbone of his family's economy and is often passed down to the next generation. The students' choice of street vendor, in this case, leans towards those who were not relocated by the Surabaya municipal government to a number of street vendor centers owned by the government, which is currently being developed at various corners of the city.

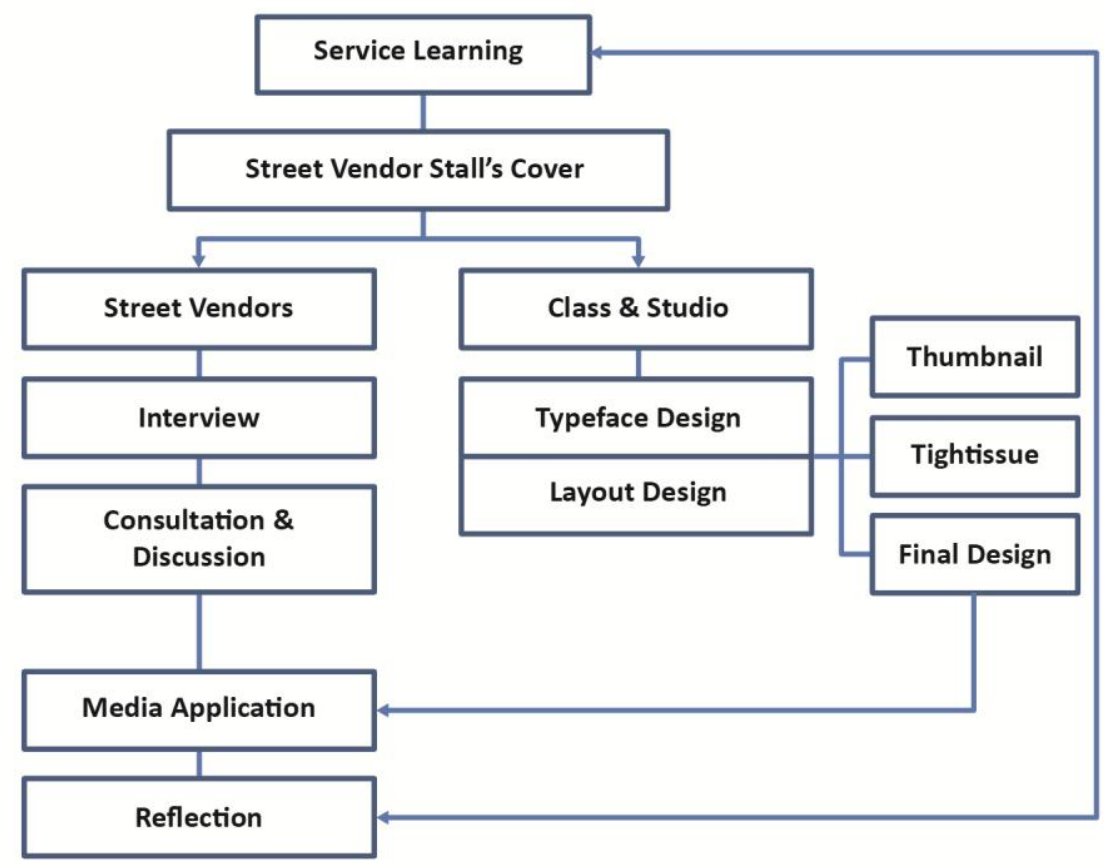

Fig. 2. Service-learning process. 


\subsection{Execution}

In relation to the stage of research, the researcher recorded the following conditions: the typeface design process began with interviews with the street vendors. Next, each member of the group created two thumbnail designs. The tutor proceeded by selecting the top two designs in each group to be made as thigh tissue and then chose one of them as the final design for the stall cover. No significant issue had occurred up to this stage (look at Fig. 2). According to observations and interviews with the students, their initial issues were often the characteristics of wall paint used to paint the cover stall. Another difficulty was the fabric application, which was something of a novelty to them. However, the interviews also revealed that the instructions were also comprehensive and they were able to solve the problem through several trials. The issue appeared when the students did not follow the given instruction or procedure to the letter. There are two issues found in regards to this: The first issue is related to the selection of stall cover fabric which is too thin, making the wall paint seep entirely to the other side. The second issue is the students' failure to use newspapers as the base for painting on fabric as was instructed by the tutor. To solve this issue, several students or groups cover the back of the painted fabric with similar fabric so that the stall cover appears neat and clean on both sides. In several groups, the size of stall cover was too big or too small compared to the available space.

\subsection{Application}

During application of stall covers, there were several interesting findings regarding the whereabouts of the cover after having been installed by the students. It turns out that not all street vendors put up the S-L cover for various reasons. The researcher found three distinct situations as follows: i) The stall cover is still installed to this moment, ii) The stall cover is no longer installed, or had been installed for a certain period of time, iii) The stall cover was never installed, except during documentation.

In the first situation, several street vendors are found with the stall cover in a maintained or less-maintained state. Installed stall cover has experienced desaturation of color and becomes dirty. This is probably due to exposure to sunlight and rain over the course of more than 7 mo. This is understandable considering that the stall cover is located outdoors. However, some street vendors placed the stall covers indoors and maintained them in good condition. The reason behind that decision is because the stall cover looked good and its material thick enough and they were afraid it would degrade if installed outdoors. According to the author, the street vendors were not entirely correct targets considering that their business is mobile in nature. However, considering that the street vendors have limited capital, the research believes that it's acceptable. The third is a special situation entailing an installed stall cover which is not used according to its purpose. This was found in the case of a street vendor in Kutisari area, who used his stall cover as a shelter during heat or rain. This is, of course, an unexpected result. The last issue is an installed stall cover but which is not positioned properly and visible from certain angles.

The second situation is that not all street vendors are using or installing the stall cover created by the students. Regarding this matter, their reasons were as follows: the stall cover was damaged because of friction with sharp objects on the installation spot, or the previous cover belonging to the street vendor was sponsored and therefore must be put up according to contract. Regarding the first aforementioned issue, the researcher believes it to be an unforeseen situation and is therefore acceptable. However, the researcher believes that the second situation could be avoided. 


\subsection{Evaluation}

The evaluation mentioned herein is a process carried out by the students, including the creation of written report and reflection and the process of documentation and evaluation by the researcher in his/her capacity as a teacher. The students successfully created a stall cover according to their study instructions. Based on the students' report, there were no significant issues which hampered them from finishing their assignments. All students had a positive experience throughout the S-L. Through documentations in the form of photographs and short videos, the researcher was able to follow through with the process and stages of all sixteen S-L groups. Therefore, the distribution of assignments between small groups did not hamper the students in learning and being active throughout the entire S-L process.

An evaluation carried out by the researcher after 7 mo of S-L was deemed long enough to identify the impacts felt by the street vendors through interviews and discussion with students, street vendors and customers. The result of interviews with street vendors is described in the following section. From the students' perspective, the researcher found a number of benefits. The students said that the S-L activity resulted in many benefits for having to meet directly with clients and therefore practicing the attitude of a professional designer. The students were also able to understand how the client thinks despite requiring more time at the beginning. They were trying to understand the client and finding the correct design solution to their needs. Knowledge about a client candidate is deemed to have increased their flexibility in performing Q\&A to upstart their partnership. It is important to note that the emergence of a sense of meaning and being needed by the society is another positive aspect which inspired them to repeat their S-L participation or initiate similar programs in the future.

In an interview with one of the stall customers, they expressed their appreciation towards this form of partnership, which not only promoted the street vendor's business but also contributed to the students' work experience in the future.

When it comes to the use of stall cover, aside from the general benefits obtained by the street vendors, there are also several other situations regarding the cover's durability or period of use by each street vendor. It was found on the fields that: out of 32 street vendors who were made targets of S-L, 11 were still using S-L stall cover. There were 10 street vendors used it for 1 mo to 3 mo and three others did not use it at all due to the stall cover not being long enough, that they were still under contractual obligations with the sponsor and the font not being large enough. Surprisingly, there was 1 street vendor changed its commodity right after S-L ended, and 1 street vendor moved out of town while nine other street vendors were nowhere to be found, which mean the cover stall might be useless.

\section{Discussion}

The researcher obtain a fact that the street vendors found the S-L program which produces cover stall for Surabaya's street vendor has extremely useful and must even be improved because the students were able to integrate with the society where Petra Christian University is located. That means as the main subject in Visual Communication Design Typography class has played an important role according to knowledge implementation outside the class that is very important for their future profession. Students learn to applicate their knowledge and skills and at the same time society gets the profit of it. This is seen as an urgent matter because, throughout the years, students are regarded as exclusive individuals who never mingled with the common folk so they lack real experience in their field of study.

The researcher also found a chance in Typography implementation that improvements 
can be made in the form of different kinds of social assistance, such as stall design or menu list as was suggested by several street vendors. Regarding a small number of street vendors who could not be evaluated, the researcher made this as a suggestion for the teacher to anticipate similar circumstances in the future to optimize the service-learning's benefit for those who involved.

During the S-L process, the street vendors felt that the students have done an adequate job in following up with their relationship since the beginning. The students had good behavior from the early stages of S-L and maintained a good relationship with the street vendors. Throughout the design consulting process, the students were able to mingle with the street vendors and no significant issues had occurred, far from the concerns of the researcher regarding the wide social gap between them.

During the survey, the researcher found that the students visited the street vendors 3 times to 4 times to conduct the survey which means student took it seriously. It followed by a design consulting session and finally the stall cover installation. This means that the students are able to conduct partnership procedures properly according to instructions. At the end of their partnership, the street vendors and students made a photo together to confirm that the partnership has indeed resulted in a stall cover as required in the syllabus of Typography 2 course. Next, the first benefit felt by street vendors was that their stall became more comfortable and shaded, especially when they did not have any cover, to begin with. For the street vendors, the new stall cover also gave them a clear identity since many among them never paid attention to their own identity. Furthermore, the students' design had an esthetical value which made them happy and even proud to be in the partnership. In terms of design, several street vendors gave inputs such as additional color, stripes or certain images to the design elements, but most were confident in the students' own design. As such, there were no significant issues with the design. The new stall cover features the name of the stall owner and their food products in a clearer and more attractive manner. This has incited confidence in them. Nevertheless, the researcher found that the recent design did not adequately feature all of their food products. As a result, the stall owner had to add several elements to the stall cover. As such, the design revision initiatives had actually come from two directions, which means that the street vendor's needs have been fulfilled by the students despite several lacks due to the students' own limitations. It's that sense of belonging which brought significance and needs to this S-L model's implementation in the classroom. For future references, such issues must be anticipated by the teacher and tutors to improve the execution of S-L program.

In regards to the selection of fabric for stall cover, the street vendors saw it as a good choice since it's more durable than what they had been using, made of outdoor vinyl. This also means saving approximately IDR 300000 to make a new stall cover. It provided quite a high value to them.

\section{Conclusion}

The implementation of service-learning in Typography class to design the cover of street vendor stalls in Surabaya benefited both parties as stated above. Throughout this program students had learn from the society. They learn how to service the society through solving their problem. Based on work-base learning theory, this service-leraning program provide an opportunity for students to develop their attitude, knowledge, skills, enlightenment, behavior, habits at campus and workplace, possibly resulting in real work activity learning. Furthermore the students simultaneously contribute to the society on one side. As the result a certain emotional tie was created between the students and the environment in which they study which is important for their personal social sensitivity. On the other side, academically, the students practiced the Typography skills that they obtained in the 
classroom and at the same time developed the awareness and professionalism at the earliest possible for the future.

The stages of preparations and execution of S-L were carried out effectively and no significant issues had hampered the students. However, generally speaking, the researcher found the following significant aspects throughout the S-L regarding its evaluation from the students' perspective:

i) A good adaptation with the street vendors can prevent issues of disparate communications. A group was particularly less effective in this regard and wasn't able to obtain complete information on the stall owner's cultural or historical backgrounds. If this issue can be mitigated at the earliest possible, it can help prevent further complications such as change of business, relocation of street vendors and the inaccurate size of stall cover in terms of location and safety.

ii) The lack of observation of fellow street vendors can result in the design being less competitive or attractive to the consumers.

iii) The students' lack of design meticulousness may result in the loss of a number of significant details on the stall cover.

iv) Good teamwork may assist in the smooth operations of group assignment. On the contrary, a bad teamwork may result in difficulties or delays in work completion.

v) Inefficient time management may result in an inaccurate choice of S-L target and eventually ineffective or wasteful stall cover design. This has negative impacts on the completion time or design quality of the stall cover.

vi) Minimum experience in using the tools and material for stall cover may be remedied through more practices before designing the real-life-sizes stall cover. This provides a special input for the teachers.

\section{References}

1. M.N. Damajanti. International Journal of Visual Design, 10, 4:17-28 (2016). http://repository.petra.ac.id/17578/

2. L.J. Moleong. Metode penelitian kualitatif edisi revisi [Qualitative research method revise edition]. Bandung: PT. Remaja Rosdakarya (2010). pp. 6-7. [in Bahasa Indonesia]. $\quad$ https://www.goodreads.com/book/show/6388482-metode-penelitiankualitatif

3. Petra Christian University. Pelaksanaan panduan service learning di Universitas Kristen Petra [Petra Christian University guidelines for serive-learning] [Online] from http://abdimas.petra.ac.id/download/material/SL_Handbook.pdf (2013). [Accessed on 27 June 2017]. [in Bahasa Indonesia].

4. H.A. Berry, L.A. Chishol. Service-learning in higher education around the world, an initial look [Online] from https://eric.ed.gov/?id=ED439654 (1999). [Accessed on 26 June 2017].

5. R.L. Lynch, D. Harnish. Preparing pre-service teachers education students to used work-based strategies to improve instruction. In Contextual Teaching And Learning: Preparing Teachers To Enchance Student Success. In: The workplace and beyond [Online] from https://eric.ed.gov/?id=ED427263 (1998). [Accessed on 28 June 2017].

6. M. Moore, P.L. Lin. Emerging service-learning paradigms in higher education. In: Service-learning in higher education, pradigms \& challenges. M. Moore, P.L. Lin (Eds). Indianapolis: University of Indianapolis Press (2009). p. 2. https://books.google.co.id/books?id=psPbTqghTrUC\&pg=PR11\&source=gbs_selected pages $\&$ cad $=3 \# \mathrm{v}=$ onepage $\& \mathrm{q} \& \mathrm{f}=$ false 
7. L. Natadjaja. International Journal of Visual Design, 6, 2:33-45 (2013).

http://repository.petra.ac.id/15987/1/G12_36042_TheImplementationofVisualCommun icationDesignMediaafterConductingServiceLearningPrograms final.pdf

8. UNESCO. Module 3 for social work [Online] from http://www.unesco.org/education/mebam/module_3.pdf (1999). [Accessed on 28 June 2017 ]

9. R. G. Bringle, S. G. Jones, G. R. Pike. Faculty perceptions of civic engagement and service-learning. In: Service-Learning in Higher Education, Pradigms \& Challenges. M. Moore, P. L. Lin (Eds). Indianapolis: University of Indianapolis Press. p. 30 (2009). https://books.google.co.id/books?id=psPbTqghTrUC\&pg=PR11\&source=gbs_selected pages \&cad $=3 \# \mathrm{v}=$ onepage $\& \mathrm{q} \& \mathrm{f}=$ false.

10. R. D. Crabtree. Michigan Journal of Community Service Learning, 15, 1(Fall):18-36 (2008). https://quod.lib.umich.edu/m/mjcsl/3239521.0015.102/--theoreticalfoundations-for-international-service-learning? $\mathrm{g}=$ mjcslg; $;$ iew=image; $\mathrm{xc}=1$ 